\title{
PENGARUH ZUMBA TERHADAP KADAR GULA DARAH
}

\author{
${ }^{1}$ Novia P. I. Benaino \\ ${ }^{2}$ S. H. R. Ticoalu \\ ${ }^{2}$ Djon Wongkar
}

\author{
${ }^{1}$ Kandidat Skripsi Fakultas Kedokteran Universitas Sam Ratulangi Manado \\ ${ }^{2}$ Bagian Anatomi-Histologi Fakultas Kedokteran Universitas Sam Ratulangi Manado \\ Email: novia.benaino@yahoo.com
}

\begin{abstract}
Glucose is the result of carbohydrate metabolism that is converted and absorbed by bloodstream and placed to several organs and body tissues that functions as the main source of energy for muscles, physical activities of the body, central nervous system and brain work. A normal glucose level value is maintained by the body in a narrow range which is about $70-120$ $\mathrm{mg} / \mathrm{dl}$. Glucose that has formed in its use as an energy source requires physical activities and insulin to stimulate permeability of the fiber muscle. This research aims at finding the effect of zumba to the blood glucose levels. Method: This research is an experiment with a one group pre and post test design that fulfill the criteria such as normal body mass index $(18,5-22,9)$, people with no exercise routine, no diabetes mellitus, no asthma, no heart disease, no broken bones on hands and feet, and not being injured in muscle joints. The research samples are twenty students of nursing program study batch 2013, Faculty of Medicine, Sam Ratulangi University. the blood glucose level is measured before and after zumba exercise. The data are analyzed by Paired Sample-T test using SPSS. Conclusion: Based on the research done on the twenty research subjects, the result shows that there is no significant change of blood glucose levels after the two-week zumba exercise.
\end{abstract}

Keywords: zumba, blood glucose.

\begin{abstract}
Abstrak: Gula darah adalah hasil metabolisme karbohidrat yang terkonversi kemudian terabsorbsi oleh aliran darah dan ditempatkan ke berbagai organ dan jaringan tubuh dengan fungsi sebagai sumber energi utama bagi otot, aktivitas fisik tubuh, sistem saraf pusat dan kerja otak. Nilai kadar glukosa normal dipertahankan oleh tubuh dalam suatu rentangan nilai yang sempit yaitu sekitar 70-120 mg/dl. Glukosa yang telah terbentuk dalam penggunaannya sebagai sumber energi memerlukan aktivitas fisik dan kerja insulin untuk merangsang permebealitas dari serabut otot.Penelitian ini bertujuan untuk mengetahui pengaruh zumba terhadap kadar gula darah. Metode: Penelitian ini bersifat eksperimental dengan rancangan one group pre and post test yang memenuhi kriteria-kriteria yaitu tidak rutin berolahraga, IMT normal (18,5-22,9), bukan penderita penyakit diabetes melitus, bukan penderita penyakit asma, bukan penderita penyakit jantung, bukan penderita patah tulang pada kaki dan tangan, tidak sedang mengalami cedera otot dan sendi. Sampel penelitian yaitu mahasiswi Program Studi Ilmu Keperawatan Fakultas Kedokteran angkatan 2013 Universitas Sam Ratulangi Manado yang berjumlah 20 orang. Kadar gula darah diperiksa sebelum dan sesudah zumba. Data dianalisis dengan Paired Sample T-test menggunakan SPSS. Simpulan: Berdasarkan penelitian yang telah dilakukan pada subjek penelitian diperoleh hasil yaitu tidak terjadi perubahan kadar gula darah yang bermakna setelah melakukan zumba selama dua minggu.
\end{abstract}

Kata kunci: zumba, gula darah. 
Tubuh manusia memerlukan asupan gizi seimbang untuk melaksanakan fungsinya secara normal yaitu asupan gizi dengan kandungan zat gizi sumber tenaga, zat gizi sumber pembangun, dan zat gizi sumber pengatur yang berasal dari makanan dan minuman yang dikomsumsi setiap hari yakni karbohidrat, protein, lemak, mineral, vitamin dan air. ${ }^{1}$

Zat gizi utama yang diperlukan oleh tubuh dalam jumlah besar yaitu karbohidrat, protein dan lemak. Zat-zat gizi ini berasal dari bahan makanan yang biasanya tidak diserap dalam bentuk alami melalui mukosa saluran pencernaan dan karena alasan ini, bahan-bahan tersebut tidak berguna sebagai zat nutrisi tanpa pencernaan awal. ${ }^{2}$

Zat gizi yang dibutuhkan dalam persentase terbanyak sesuai dengan persentase terhadap kebutuhan total kalori yaitu karbohidrat sebesar 55-67\%. Karbohidrat merupakan komponen makanan yang tidak larut di dalam air, terdiri dari karbon, oksigen dan hidrogen sebagai sumber energi utama yang mudah dicerna dan dapat digunakan dengan cepat. ${ }^{1,3}$

Karbohidrat yang dikomsumsi mengalami proses pencernaan di dalam tubuh dan terkonversi menjadi glukosa untuk kemudian terarbsorbsi oleh aliran darah dan ditempatkan ke berbagai organ dan jaringan tubuh dengan fungsi sebagai sumber energi utama bagi otot, aktivitas fisik tubuh, sistem saraf pusat dan kerja otak, selain itu karbohidrat yang dikomsumsi juga disimpan dalam bentuk cadangan energi yaitu glikogen pada otot dan hati. ${ }^{4}$

Di dalam tubuh manusia, total karbohidrat yang dapat tersimpan kurang lebih sebesar 500 gram atau mampu untuk menghasilkan energi sebesar 2000 kkal, sekitar $80 \%$ dari karbohidrat ini akan tersimpan sebagai glikogen di dalam otot, 18-22\% akan tersimpan sebagai glikogen di dalam hati dan sisanya akan bersirkulasi di dalam aliran darah dalam bentuk glukosa. Proses pembakaran satu gram karbohidrat menghasilkan energi sebesar empat kkal. Pada saat berolahraga terutama olahraga dengan intensitas sedang sampai intensitas tinggi, kebutuhan energi bagi tubuh dapat terpenuhi melalui simpanan glikogen, terutama glikogen otot serta melalui simpanan glukosa yang terdapat di dalam aliran darah dimana ketersediaan glukosa di dalam aliran darah ini dapat dibantu oleh glikogen hati agar levelnya tetap berada pada keadaan normal. ${ }^{5}$

Keseimbangan glukosa dipengaruhi oleh fungsi hormon insulin dan hormon glukagon dimana fungsi kedua hormon ini berbeda yaitu fungsi insulin adalah untuk meningkatkan pengambilan banyak glukosa oleh sel sehingga kadar gula darah menurun sedangkan fungsi glukagon adalah untuk meningkatkan sintesis glukosa dari hati ke dalam darah sehingga kadar gula darah meningkat. $^{2}$

Glukosa yang telah terbentuk dalam penggunaannya sebagai sumber energi memerlukan aktivitas fisik dan kerja insulin untuk merangsang permebealitas dari serabut otot sebab membran otot dalam keadaan istirahat yang normal hanya sedikit permeable terhadap glukosa kecuali apabila serabut otot dirangsang oleh insulin akan tetapi pada saat tubuh melakukan aktivitas fisik dengan intensitas sedang atau intesitas berat, penggunaan glukosa yang besar ini tidak membutuhkan sejumlah besar insulin karena serabut otot yang bekerja menjadi permeable terhadap glukosa bahkan tanpa adanya insulin akibat proses kontraksi otot itu sendiri. ${ }^{2}$

Perubahan gaya hidup seperti diet dan kebiasaan olahraga yang salah merupakan faktor resiko predisposisi terjadinya resistensi insulin yang dapat mengakibatkan ketidakseimbangan glukosa. Kadar glukosa dapat dikendalikan melalui gaya hidup yang sehat, pola makan yang benar serta aktivitas fisik yang teratur. Anjuran olahraga atau latihan fisik sebetulnya bukan merupakan hal yang baru sebelum ditemukannya insulin pada tahun 1921, namun pada waktu itu belum jelas batasan latihan fisik yang harus dilakukan seperti jenis latihan, dosis, frekuensi maupun intensitas dari latihan. ${ }^{6}$

Salah satu aktivitas fisik yang dapat dilakukan untuk menurunkan kadar glukosa yaitu melalui suatu inovasi aerobik melalui iringan musik irama Latin berupa tarian gerakan-gerakan baru hasil perpaduan unsur koreografi dan musik Amerika Latin seperti 
Salsa, Merengue, Mambo, Cha-cha, Cumbio, Flamenco, Tango, dan Bachala yang disebut zumba. ${ }^{7}$

\section{METODE PENELITIAN}

Jenis penelitian ini yaitu eksperimental one group pre and post test design dengan jumlah sampel 20 mahasiswi Program Studi Ilmu Keperawatan angkatan 2010 Universitas Sam Ratulangi Manado yang memenuhi kriteria yaitu tidak rutin berolahraga, indeks massa tubuh normal, bukan penderita penyakit diabetes melitus, bukan penderita penyakit asma, bukan penderita penyakit jantung, bukan penderita patah tulang pada kaki dan tangan, tidak sedang mengalami cedera otot dan sendi. Pengambilan sampel darah sebelum zumba dilakukan pada hari pertama sebelum melakukan zumba, subjek penelitian diwajibkan berpuasa minimal delapan jam sebelum pengambilan darah. Latihan zumba dilakukan setiap tiga kali seminggu pada sore hari selama satu jam. Pengambilan sampel darah sesudah zumba dilakukan pada pagi hari, setelah hari terakhir melakukan zumba, subjek penelitian diwajibkan berpuasa minimal delapan jam sebelum pengambilan darah. Pengambilan sampel darah melalui vena mediana cubiti dan langsung diperiksa dengan menggunakan alat easy touch GCHb. Data dianalisis dengan Paired Sample T-test menggunakan SPSS

\section{HASIL}

Distribusi karakteristik menurut usia subjek penelitian dapat dilihat pada tabel 1 .

Tabel 1. Distribusi usia subjek penelitian

\begin{tabular}{c|c|c}
\hline Usia & Frekuensi & $\mathbf{\%}$ \\
\hline 16 & 1 & 5,0 \\
17 & 4 & 20,0 \\
18 & 13 & 65,0 \\
19 & 2 & 10,0 \\
Total & 20 & 100 \\
\hline
\end{tabular}

Distribusi karakteristik menurut berat badan (BB), tinggi badan (TB) dan Indeks Massa Tubuh (IMT) subjek penelitian dapat dilihat pada Tabel 2.

Tabel 2. Distribusi berat badan, tinggi badan dan IMT subjek penelitian

\begin{tabular}{cccc}
\hline Klasifikasi & $\begin{array}{c}\text { TB } \\
(\mathbf{c m})\end{array}$ & $\begin{array}{c}\text { BB } \\
\mathbf{( k g )}\end{array}$ & $\begin{array}{c}\text { IMT } \\
\left.\mathbf{( K g} / \mathbf{m}^{2}\right)\end{array}$ \\
\hline Rata-rata & 154,3 & 48,3 & 20,2 \\
Std.Deviasi & 5,137 & 4,073 & 1,250 \\
Nilai Maks. & 165,8 & 61 & 22,7 \\
Nilai Min. & 147,2 & 40,2 & 18,5 \\
\hline
\end{tabular}

Pengukuran kadar gula darah pada subjek penelitian dilakukan dengan cara pengambilan sampel darah melalui vena mediana cubiti yang kemudian langsung diperiksa menggunakan alat Easy Touch GCHb.

Distribusi kadar gula darah subjek penelitian sebelum dan sesudah melakukan latihan zumba dapat dlihat pada Tabel 3.

Tabel 3. Distribusi kadar gula darah sebelum dan sesudah latihan zumba

\begin{tabular}{ccc}
\hline Klasifikasi & $\begin{array}{c}\text { Gula Darah } \\
\text { sebelum } \\
\text { (mg/dl) }\end{array}$ & $\begin{array}{c}\text { Gula Darah } \\
\text { sesudah } \\
\text { (mg/dl) }\end{array}$ \\
\hline Rata-rata & 120,5 & 122,3 \\
Std. Deviasi & 8,864 & 4,815 \\
Nilai Maks. & 138 & 132 \\
Nilai Min. & 101 & 116 \\
\hline
\end{tabular}

Uji persyaratan analisis yang digunakan dalam penelitian ini yaitu Shapiro-Wilk. Pengujian dilakukan sebelum data dikelolah untuk menguji hipotesis yang ada. Hasil uji normalitas dapat dilihat pada tabel 4 .

Tabel 4. Hasil uji normalitas

\begin{tabular}{ccc}
\hline Gula Darah & Shapiro-Wilk & Keterangan \\
\hline Sebelum & 0,872 & Normal \\
Sesudah & 0,144 & Normal \\
\hline
\end{tabular}


Hasil perhitungan dengan menggunakan Paired Sample T-test pada statistical program for social science 20 (SPSS20). kadar gula darah sebelum dan sesudah latihan zumba selama dua minggu dapat dilihat pada tabel 5 .

Tabel 5. Hasil perhitungan dengan menggunakan Paired Sample T-test kadar gula darah sebelum dan sesudah selama dua minggu

\begin{tabular}{ccc}
\hline Test & Hasil & Keputusan \\
\hline $\begin{array}{c}\text { Paired Sample T- } \\
\text { test }\end{array}$ & 0,852 & $\mathrm{H}_{0}$ diterima \\
\hline
\end{tabular}

\section{BAHASAN}

Penelitian ini dilakukan di Fakultas Kedokteran Universitas Sam Ratulangi untuk mengetahui pengaruh zumba terhadap kadar gula darah pada 20 orang mahasiswi Program Studi Ilmu Keperawatan Universitas Sam Ratulangi angkatan 2013. Karakteristik berdasarkan usia subjek penelitian pada penelitian ini berkisar antara 16 tahun sampai 19 tahun, usia 16 tahun berjumlah satu orang dengan persentase $5 \%$, usia yang paling banyak yaitu pada usia 18 tahun yang berjumlah 13 orang dengan persentase 65\%, dan usia 19 tahun berjumlah dua orang dengan persentase $10 \%$. Karakteristik berdasarkan berat badan subjek penelitian berkisar antara $40 \mathrm{~kg}$ sampai $61 \mathrm{~kg}$ dengan berat badan rata-rata 48,340 kg. Karakteristik berdasarkan tinggi badan subjek penelitian rata-rata 154,330 cm dengan nilai minmum 147,20 cm dan nilai maksimum 165,80 cm. Karakteristik berdasarkan Indeks Massa Tubuh subjek penelitian rata-rata $20,288 \mathrm{~kg} / \mathrm{m}^{2}$.

Subjek penelitian dikumpulkan di laboratorium Anatomi-Histologi Fakultas Kedokteran Universitas Sam Ratulangi. Pengambilan sampel darah sebelum zumba dilakukan pada hari pertama, pukul 07.00 WITA di laboratorium Anatomi-Histologi Fakultas Kedokteran Universitas Sam Ratulangi, sebelumnya subjek penelitian diwajibkan berpuasa minimal delapan jam. Pengambilan sampel darah melalui vena mediana cubiti dan langsung diperiksa menggunakan alat easy touch GCHb. Latihan zumba dilakukan setiap tiga kali seminggu pada sore hari selama satu jam di Aula Fakultas Kedokteran Universitas Sam Ratulangi dipimpin oleh instruktur zumba. Pengambilan sampel darah sesudah zumba dilakukan setelah hari terakhir melakukan zumba, pukul 07.00 WITA di laboratorium Anatomi-Histologi Fakultas Kedokteran Universitas Sam Ratulangi, sebelumnya subjek penelitian diwajibkan berpuasa minimal delapan jam. Pengambilan sampel darah melalui vena mediana cubiti dan langsung diperiksa menggunakan alat easy touch GCHb.

Kadar gula darah rata-rata sebelum zumba adalah 120,550 mg/dl dengan nilai minimum $101 \mathrm{mg} / \mathrm{dl}$ dan nilai maksimum $138 \mathrm{mg} / \mathrm{dl}$. Kadar gula darah rata-rata sesudah zumba adalah 122,350 $\mathrm{mg} / \mathrm{dl}$ dengan nilai minimum $116 \mathrm{mg} / \mathrm{dl}$ dan nilai maksimum $132 \mathrm{mg} / \mathrm{dl}$. Kadar gula darah sebelum dan sesudah zumba memiliki perbedaan dimana kadar rata-rata gula darah sebelum zumba sedikit lebih rendah dibandingkan kadar rata-rata gula darah sesudah zumba yaitu 120,550 mg/dl banding $122,350 \mathrm{mg} / \mathrm{dl}$.

Berdasarkan perhitungan menggunakan uji Shapiro-Wilk kadar gula darah sebelum dan sesudah zumba, didapatkan hasil sebelum zumba sebesar 0,872 dan sesudah zumba sebesar 0,144 . Suatu data dinyatakan berdistribusi normal jika probablitasnya lebih besar dari 0,05. Dari hasil yang didapatkan yaitu 0,872 dan 0,144 (lebih dari 0,05) maka dinyatakan data berasal dari populasi yang berdistribusi secara normal.

Uji hipotesis dilakukan dengan cara Paired Sample T-test menggunakan Statistical Program for Social Science 20 (SPSS 20). Pengujian tentang sebaran data telah dilakukan dan hasilnya secara statistik tidak ada perubahan yang signifikan. Nilai $p$ yang didapatkan adalah 0,852 . Nilai p lebih besar dari 0,05 maka $\mathrm{H}_{0}$ diterima dengan arti bahwa tidak terdapat perubahan kadar gula darah yang bermakna setelah melakukan zumba selama dua minggu. 
Kadar gula darah puasa normal harus dipertahankan di bawah 126 mg/dl Kadar gula darah puasa normal harus dipertahankan di bawah $126 \mathrm{mg} / \mathrm{dl}$ melalui lebih dari satu kali pengukuran, hasil pemeriksaan rata-rata kadar gula darah sebelum dan sesudah zumba adalah 120,550 $\mathrm{mg} / \mathrm{dl}$ dan 122,350 mg/dl. Hasil ini cukup tinggi jika ditinjau dari patokan penyaringan dan diagnosis Diabetes Melitus dimana kadar gula darah puasa plasma vena seharusnya di bawah $100 \mathrm{mg} / \mathrm{dl}$. Namun hasil rata-rata pemeriksaan kadar gula darah sebelum dan sesudah zumba tidak secara pasti atau belum pasti memberikan penilaian adanya diabetes melitus, karena banyak faktor yang dapat mempengaruhi kadar gula darah sebelum dan sesudah zumba. ${ }^{8,9}$

Menurut pedoman industri kebugaran yang diterima saat ini, seseorang harus latihan antara 64-94\% dari HR max atau 40$85 \%$ dari $\mathrm{VO}_{2}$ max untuk meningkatkan kebugaran kardiovaskular. Lebih lanjut ACSM merekomendasikan bahwa individu menghabiskan $300 \mathrm{Kkal}$ atau latihan untuk menurunkan berat badan dan mempertahankan berat badan yang sehat, dengan demikian partisipasi reguler pada zumba harus positif mempengaruhi komposisi tubuh. $^{10}$

Pada saat berolahraga tubuh akan menyiapkan tenaga dalam glukosa. Untuk olahraga aerobik yang porsi latihannya antara $60-80 \%$ dari kemampuan maksimal ambilan oksigen $\left(\mathrm{VO}_{2}\right.$ max), maka glukosa yang dibakar meningkat hingga 7-20 kali lipat dibandingkan saat istirahat, terutama pada 30 menit pertama latihan yang akan mencapai 50\% dari kebutuhan total tubuh. ${ }^{11}$

Denyut jantung subjek penelitian zumba dapat menjadi patokan untuk memperkirakan konsumsi oksigen untuk menentukan pengeluaran kalori. Aktivitas zumba dengan hasil denyut jantung rata-rata 154 bpm (79\%HR max) dan pengeluaran kalori rata-rata 370 kkal menunjukan bahwa zumba merupakan olahraga kebugaran alternatif yang tepat. ${ }^{12}$

Latihan fisik dapat meregulasi kadar gula darah melalui peningkatan regulasi insulin sebagai hasil dari proses latihan yang mekanismenya masih belum diketahui. Translokasi yang disebabkan oleh latihan sampai saat ini belum jelas, tetapi dapat diterangkan melalui pelepasan ion kalsium dari sarkoplasmatik retikulum yang menyebabkan proses kontraksi. Ion kalsium ini akan mengaktifkan PI3-K dan Protein Kinase $\mathrm{C}$ yang diduga mengakibatkan translokasi GLUT-4 yang menyebabkan peningkatkan pengambilan glukosa. ${ }^{13}$

Kontraksi otot merangsang pengangkutan glukosa secara langsung dan aksi insulin independen dengan menginduksi pengangkut GLUT-4 ke permukaan sel. Tingkat maksimal pengangkutan glukosa otot ditentukan oleh total konsentrasi GLUT-4 dan proporsi yang translokasi ke membran sel sebagai respon terhadap insulin dan kontraksi otot. ${ }^{14}$

Pengaturan kadar gula darah sangat erat kaitannya dengan hormon insulin dan glukagon pankreas. Peningkatan kadar glukosa darah merangsang sekresi insulin untuk berperan dalam meningkatkan metabolisme dan pengambilan glukosa oleh otot, penyimpanan glikogen di otot, membantu transport glukosa melalui membran sel otot, serta meningkatkan pengambilan, penyimpanan dan penggunaan glukosa di hati. Selain insulin dan glukagon, sistem saraf pusa, terutama hipotalamus dan batang otak memiliki peranan penting kunci dalam homeostasis glukosa, bukan saja melalui penggunaan glukosa sebagai bahan bakar utama untuk menjalankan fungsi tetapi sebagai bagian dari sirkuit saraf yang rumit yang terlibat dalam penyerapan glukosa. ${ }^{15}$

Pada penelitian ini subjek penelitian tidak dikontrol sepenuhnya dalam hal mengatur dan menjaga pola makan selama dua minggu diberi perlakuan zumba dan setelah hari terakhir mengikuti zumba, Subjek penelitian dihimbau untuk makan sesuai dengan pola makan subjek penelitian seperti biasanya namun tetap aktif untuk mengikuti zumba selama dua minggu, dengan demikian dapat dilihat apakah ada pengaruh zumba terhadap kadar gula darah subjek penelitian yang hidup dengan pola makan seperti biasanya tanpa dikontrol sepenuhnya. 
Pola makan adalah hal yang terpenting dalam menjaga kadar gula darah sebab pola makan yang berlebihan pada saat sebelum dan sesudah latihan dapat mengakibatkan hiperglikemia atau mem-berikan efek negatif bagi sistem metabolik dan manfaat vaskuler lainnya. $^{16}$

Waktu pengambilan sampel darah antara latihan zumba yaitu pengambilan darah baik sebelum dan sesudah zumba harus diperhatikan. Seperti yang telah dijelaskan sebelumnya, pengambilan darah sebelum zumba dilakukan pada pagi hari dan zumba dimulai pada sore hari selama tiga kali seminggu, demikian juga pada pengambilan sampel darah sesudah zumba, dimana zumba dilakukan pada sore hari dan pengambilan sampel darah dilakukan keesokan harinya. Jedah waktu yang terlalu lama dalam pengambilan sampel darah sangat mempengaruhi konsentrasi glukosa darah yang terutama disebabkan oleh pola makan subjek penelitian sesudah zumba, walaupun subjek penelitian wajib berpuasa minimal delapan jam sebelum pengambilan sampel darah, jenis makanan dan jumlah makanan yang dikomsumsi pada hari terakhir melakukan zumba juga berpengaruh terhadap hasil pemeriksaan kadar gula darah pada keesokan harinya. Perlu ditentukan waktu yang tepat antara pengambilan sampel darah sebelum zumba-zumba selama dua minggu-sesudah zumba, dengan melihat puncak gula darah dalam plasma setelah makan. Puncak gula darah plasma setelah makan bervariasi antar individu sesuai dengan jenis makanan yang dikonsumsi, seberapa cepat seseorang mengkonsumsi makanan, jumlah makanan yang dikonsumsi, seberapa kuat ikatan karbohidrat pada makanan serta kemampuan sistem pencernaan dan metabolisme. Ratarata puncak gula darah plasma setelah makan dicapai antara 60 sampai 75 menit. ${ }^{17}$

Saat latihan fisik seperti zumba, gula darah dapat mengalami peningkatan dengan cepat sekitar 7-20 kali dibandingkan saat istrahat, meskipun gula darah plasma awalnya rendah. Peningkatan $\mathrm{Ca}^{2+}$ dan faktor lain berhubungan dengan peningkatan jumlah transporter gula darah yang meningkatkan transpor membran untuk glukosa. Glukosa plasma dipertahankan selama latihan fisik dengan meningkatkan glukoneogenesis, dan menurunkan pengambilan glukosa oleh jaringan. Penurunan insulin plasma dan peningkatan epinefrin, norefineprin, growth hormon, glukagon dan kortisol selama latihan mengontrol mekanisme-mekanisme ini untuk mempertahankan konsentrasi glukosa. ${ }^{12,17}$

Akan tetapi setelah istrahat konsentrasi glukosa akan kembali normal. Menentukan waktu yang tepat untuk pengambilan sampel darah sangat penting dalam pengukuran gula darah sesudah zumba. Pengambilan dan pemeriksaan darah secara berturutan setelah latihan seperti 30 menit, satu jam, dan dua jam dianjurkan untuk meneliti turn over glukosa plasma pasca latihan zumba. ${ }^{17}$

Penelitian dari Little, menemukan bahwa setelah latihan fisik rata-rata penurunan glukosa sebesar $13 \%$ setelah 24 jam. Kjaer dkk, menemukan peningkatan glukosa setelah latihan fisik sampai 30 menit dan menurun setelah itu. Harmer dkk, peningkatan glukosa darah sampai 20 menit setelah latihan fisik dan menurun sesudah itu. $^{17}$

Dari penelitian tersebut dapat diambil patokan pemeriksaan penurunan glukosa darah setelah latihan zumba adalah 30 menit sampai satu jam, dimana pengaruh glukogenesis yang meningkatkan glukosa darah selama latihan fisik, telah berkurang. ${ }^{18}$

\section{SIMPULAN}

Berdasarkan hasil penelitian yang didapatkan, maka disimpulkan bahwa tidak terdapat pengaruh zumba terhadap kadar gula darah setelah melakukan zumba selama dua minggu.

\section{SARAN}

1. Perlu dilakukan penelitian lanjutan dengan jangka waktu yang lebih dari dua minggu

2. Perlu dilakukan penelitian lanjutan dengan mempertimbangkan waktu pengambilan sampel darah sebelum dan sesudah zumba 
3. Subjek penelitian sebaiknya dikarantina selama penelitian agar dapat dikontrol dengan baik

4. Perlu dilakukan penelitian lanjut dengan rancangan penelitian yang lebih baik

\section{UCAPAN TERIMA KASIH}

Ucapan terima kasih disampaikan kepada dr. S. H. R. Ticoalu, M.Kes, AIFO, dr. Djon Wongkar, M.Kes, AIFO sebagai dosen pembimbing penulis serta kepada Dr. dr. S. Tjandra Wangko, M.Si, PA (K), Dr. dr. Taufiq Pasiak, M.Kes, M.Pd.I sebagai dosen penguji penulis dan juga kepada semua pihak baik yang secara langsung maupun tidak langsung telah menambahkan ide dan gagasan bagi penulis sehingga dapat menyelesaikan artikel ini.

\section{DAFTAR PUSTAKA}

1. Gunandi HD. Gizi Atlet Lari Cepat 100 Meter Pelajar Putra Indonesia. Jurnal Ilmiah Spirit, 2010;10: 1411-8319

2. Guyton \& Hall. Penerbit Buku Kedokteran EGC. $11^{\text {th }}$ ed. 2006. p. 849-859

3. Baskora R. Sutardji, Woro O. Sistem Infornasi Perencanaan Pola Hidup Melalui Keseimbangan Aktivitas Dan Asupan Makanan. Jurnal Media Ilmu Keolahragaan Indonesia, 2011;1: 2088-6802

4. Irawan MA. Metabolisme Energi Tubuh \& Olahraga. Polton Sport Science \& Performance Lab, 2007;1:7

5. Irawan MA. Nutrisi, Energi \& Performa Olahraga. Polton Sport Science \&

Performance Lab, 2007;1:4

6. Indriyani $\mathrm{P}$, Supriyanto $\mathrm{H}$, Santoso A. Pengaruh Latihan Fisik ; Senam Aerobik Terhadap Penurunan Kadar Gula Darah Pada Penderita DM Tipe 2 Di Wilayah Puskesmas Bukateja Purbalingga, Media Ners, 2007;1:49-99

7. Anonymous. Warta Kestra. Tubuh Bugar, Otak Sehat Dengan Zumba, 2012;158:26

8. Lintong PM. Patologi Sistem Endokrin. Manado. Fakultas Kedokteran Universitas Sam Ratulangi; 2006. p.83-94
9. Sudoyo AW, Setiyohadi B, Alwi I, K Marcellus S, Setiati S, editors. Buku Ajar Ilmu Penyakit Dalam. Jakarta: Interna Publishing; 2009

10. Luettgen M, Foster C, Doberstein S, Mikat R, Porcari J. Zumba: is the "fitness-party" a good workout?. Journal of Sport science and medicine. 2012(11); 357-8.

11. Kusmana D. Olahraga Untuk Orang Sehat dan Penderita Penyakit Jantung. $2^{\text {th }}$. Jakarta: Fakultas Kedokteran Universitas Indonesia; 2006. p. 3-28

12. Sternlicht E, Frisch F, Sumida KD. Zumba Fitness workouts: are they an appropriate alternative to running or cycling?. Sport Sci Health. No.: DOI 10.1007/s11332-0130155-8.2013.

13. Fathoni C, Irmawati A, Herawati L. Perbedaan Latihan Fisik Jangka Pendek Dan Jangka Panjang Terhadap Glukosa Darah Pada Penderita Diabetes Mellitus. Majalah Ilmu Faal Indonesia, 2007;6:141

14. Jentjens R, Jeukendrup AE. Determinants of Post-Exercise Glycogen Synthesis During Short-Term Recovery. Sports Med 2003; 33 (2): 119

15. Cristina Muntean C, Mota M, Popa S, Mitrea A. THE ROLE OF THE CENTRAL NERVOUS SYSTEM IN GLUCOSE HOMEOSTASIS. Romanian Journal of Diabetes Nutrition \& Metabolic Diseases, 2012; 19: 2

16. The Diabetes Research In Children Network (DirectNet) Study Group. The Effects Of Aerobic Exercise On Glucose And Counterregulatory Hormone Concentration In Children With Type 1 Diabetes. Diabetes Care 2006;29:20.

17. Parr BB. Hormonal responses to exercise. Dalam: Power SK, Howley ET. Exercise physiology. Theory and application to fitness and performance. University of South Carolina Aiken, 2009. p 1-7

18. Adams OP. The impact of brief highintensity exercise on blood glucose level. Open access to scientific and medical research. ADAMS, 2013. p 113-121. 